Marquette University

e-Publications@Marquette

English Faculty Research and Publications

English, Department of

$1-1-2003$

\title{
The Temple of Morality: Thomas Holcroft and the Swerve of Melodrama
}

Diane Hoeveler

Marquette University, diane.hoeveler@marquette.edu

Accepted version. European Romantic Review, Vol 14, No. 1 (2003): 49-63. DOI. (C) 2003 Taylor \& Francis (Routledge). Used with permission. 


\title{
The Temple of Morality: Thomas Holcroft and the Swerve of Melodrama
}

\author{
Diane Long Hoeveler \\ English, Marquette University \\ Milwaukee, WI
}

"Humanity is the virtue of a woman ..." Adam Smith

IN PARIS, September 1800, at the apex of Napoleon's reign, a displaced aristocrat named René Charles Guilbert de Pixerécourt (1773-1844) perfected a new dramatic form -the melodrama.

Pixerécourt had managed to survive the worst of the French Revolution by hiding in a Parisian attic, and although one would think he might have been somewhat distracted, he managed to cobble together this new hybrid genre, which in turn would prove to be one of the most lasting artistic legacies of the Revolution. His Coelina ou l'Enfant du mystère [Selena or the Child of Mystery], originally performed in 1800 at the Ambigu Theater, became the first full-fledged example of a melodrama as we understand the genre today. Also roaming around Paris during that fateful 1800 theater season was one Thomas Holcroft (1745-1809), a British Jacobin who was trolling for theatrical and novelistic ideas to bring back with him to an England he hoped would become more sympathetic to the Revolutionary cause. Holcroft noted after his trip that he saw advertisements for eighteen different theaters in Paris that season, but there were actually twenty-three in 1789 and thirty-two by 1807 (Rahill 41). Holcroft is not a name one frequently cites or sees cited, and certainly if he is remembered at all today it is as a writer of J acobin novels, a compatriot of Wollstonecraft, Inchbald, Godwin, and Helen Maria Williams. 1 But it would appear that 
it is more accurate to see Holcroft as the man who wrote-or more accurately stole-the first British melodrama from France.

Pixerécourt's Coelina became in Holcroft's hands The Tale of Mystery (Covent Garden, 1802), but as Holcroft's piece is a virtual translation of its source, its analysis has to begin with the French origins of melodrama. ${ }^{1}$

It is necessary, however, to briefly sketch Holcroft's background in order to understand the role he played in transporting the first melodrama from France to England. In the first chapters of his Life, which he himself composed (the remainder were completed by Hazlitt after his death), Holcroft tells us that both his parents were peddlers and that he spent his early years following them from town to town, eating so little that his growth was permanently stunted. In 1770, at the age of 25, he joined a troupe of traveling actors, primarily playing roles in comedies. Marrying for the first time at an early age, he found himself in need of money as his family increased. It was then that he turned to writing for the stage, as well as writing novels and translating the works of Madame de Genlis, Lavater, Frederick II, Baron Trenck, and Goethe from the French and German (Gregory 53). His first trip to France was in 1783 as a foreign correspondent for The Morning Herald, but he returned the next year with the intention of watching enough performances of Beaumarchais' thrashing of the aristocracy in Le Mariage de Figaro to present his own English version on the London stage. His adaptation, The Follies of a Night, proved unsuccessful, but the strategy of adapting a liberal French play for British audiences became one of Holcroft's primary means of support. Such productions can be understood best when ones remembers his background as a peddler, and clearly in an era in which copyright laws did not exist, Holcroft translated and published dramas the way a peddler acquires goods, marks them up, and then sells them to a consumer one town over. Completely self-educated, Holcroft's political sympathies were liberal long before the French revolution gave a focus and impetus to his beliefs. In 1783 he penned a theatrical review that made explicit his position that the theater should be institutionalized by the state in order to serve as a force to liberalize and educate the populace as a whole:

The Theatre is as well worthy the contemplation of the Philosopher and the Legislator, as the Man of Taste. We are persuaded it contributes, in its present 
state, to humanize the heart, and correct the manners. . . If it is not uniform in the tendency of its effects, it is because Legislators have never yet been sufficiently convinced of the power of the Drama, to incorporate it with the constitution, and make it a legal and necessary establishment; or rather, perhaps, because some men were fearful, lest while they were erecting the temple of morality, they should erase the tottering structure of superstition, in the preservation of which themselves, their children, or their dependents were materially interested. (Bolton 17, emphases added)

As Bolton observes, Holcroft's theories "link the civilizing force of the drama to a leveling of social classes" (17), while other critics of the period feared that the theater actually encouraged class warfare in its pitting of the audience against the theater managers (witness the Old Price Riots in 1809). Clearly, the theater has always been every society's most publicly contested space, the embodiment of a quasiutopian proscenium in the heart of the population, a ritualistic arena where social, cultural, sexual, and religious ideologies converged in staged combat, poised to battle it out for the hearts and minds of the people. In late eighteenth and early nineteenth-century British culture, however, the public-private debate took on a new urgency and the stakes were indeed high. A corrupt aristocracy sought to stave off the sort of political unrest that would shortly engulf France, and the theater was very obviously a potent weapon in either calming the populace or enflaming it. In a blatant bid to shore up British nationalism and patriotism, revivals of Shakespeare and classical works dominated the early eighteenth-century theater, but increasingly the public was attracted to works that dealt with contemporary social and political issues. Once the theater was recognized as one of the spaces where public instruction in manners, civility, and proper class-based conduct would occur, the struggle was on for control of the stage. As Bolton argues, "Romantic nationalism relied on spectacle both in appealing to the public's patriotic sentiments and in projecting a sentimental code of honor: benevolent mastery of domestic and international affairs" (21).

Where does this place Holcroft as a melodramatist with a liberal (nay, radical) political agenda? Writing in a culture where the patriarchy was both under siege and vigorously buttressed, Holcroft imported the melodrama, a mixed genre that embodied ambiguity and moral oscillation in its very nature. 2 Unable to outright condemn the corrupt king-father, Holcroft instead presented morally flawed fathers 
and sinful patriarchs who are admonished by the female and bourgeois voice of common sense in the conclusion of his plays. Such admonishment has led at least one critic to argue that The Tale of Mystery is a radical, avant-garde production, in line with Holcroft's political sympathies (Shepherd 507). And certainly there is no question about Holcroft's atheism or his Jacobin allegiances, for in addition to his work as a dramatist Holcroft was also a member of the London Corresponding Society, part of the Hardy, Tooke, and Thelwall "conspiracy" for treason against the crown in 1794. Although he was briefly held in custody, Holcroft was never tried for supposedly "imagining the King's death," but he did spend the rest of his life labeled as "an acquitted felon," and hence found attendance at his plays and purchases of his novels decline (Barrell 411-414).

In 1795, after his infamous "trial," Holcroft wrote and produced The Deserted Daughter under a pseudonym and then spent most of the rest of his adult life as an 'emigré, living in France. Gary Kelly characterizes him as an advocate of "a kind of English J acobin theology," a believer in condemning "pride, avarice, lust, wrath, gluttony, envy, and sloth" as not so much sins as "bad habits [that] are best laughed at rather than hated" (139-140). By placing Holcroft's The Deserted Daughter, a play written before his extended sojourn in France, against The Child of Mystery, a decidedly French production, we can, I think, chart almost exactly the swerve that melodrama took as it migrated to Britain. During the eighteenth century the British stage was flooded with works that employed sentimental categories clearly derived from Samuel Richardson, but after the importation and adaptation of Coelina onto the London stage, romantic drama veers off to become a distinctly hybrid genre, one that splits tragedy and comedy into something that we would recognize today as tragicomedy, an amalgam of "tears and smiles," an uncomfortable mixture of bathos and pathos, snickers and sneers. ${ }^{3}$ As always, the most interesting question for the literary historian is: why? Why would a culture want to place extreme, hyperbolic-one might say absurd-emotions on public display? And why would dramatists create the most untenable plot situations-most of which we would be charitable to recognize as unrealistic? And even more puzzling, why would lower- and middle-class audiences flock to these productions, knowing before the play began that they were soon to witness yet more variations on a few simple themes: the orphan in distress, the 
machinations of the unmasked greedy villain, the virtue of the mother, and the eventual triumph and restoration of the patriarchal family? The answers to these questions can only be discerned by starting at the beginning.

The term melodrama is itself subject to a fair amount of debate. Some critics have claimed that the term is derived the Greek word melos (music), because melo-drama originated in the mingling of music with action and spoken dialogue on stage. The Oxford Companion to Music now defines "melodrama" as "a play or passage in a play, or a poem, in which the spoken voice is used against a musical background". Theater historians, however, have suggested that the French verb mêler (to mix) is actually the origin for the term. Contrast these positions to one provided by the Oxford English Dictionary: "a dramatic piece characterized by sensational incident and violent appeals to the emotions, but with a happy ending, "4 and one can see that both literary critics and musicologists have laid claim to the genre. It is clear, however, that melodrama's origins are most accurately understood as a mixture of words and music, and that the genre has to be approached through both mediums in order to be fully appreciated as well as understood. As music (and ballet) faded from the repertoire of the romantic melodrama, some element had to be inserted to sustain the same level of audience involvement. Enter "tragedy," that is, the mute character who acts out his buried and abusive history through the dumb show that explains his extended stay in a prison or exile on a ship.

Musicologists as well as theater historians locate the origin of melodrama in Jean Jacques Rousseau's Pygmalion (Lyons 1770, Weimar 1772, Paris 1775), a short scène lyrique with libretto composed by Rousseau. Although he acknowledged that he was borrowing from the Italians, Rousseau was the first to use the term "Mélo-drame" in 1766 to describe his Pygmalion, explaining that he was using music to express emotions in a particular situation, while another actor used pantomime to act out the same scene. Only when the music concludes does the actor speak, expressing verbally what had just been communicated through gestures and accompaniment. Certainly the development of such a style suggests the continuing power of an oral-based culture. The Bohemian Georg Benda's Ariadne auf Naxos (1774) and his Medea (1775) both build on the innovations 
of Rousseau, as did J ean de Florian's Heró et Léandre (1785), which has the heroine speaking over the musical background. The next influences on the evolution of melodrama were the theatrical antics perfected at the Jacobin Boulevard du Temple, where all manner of jugglers, pantomimes, and freaks performed, juxtaposed with outlandish adaptations of fairy tales taken from Perrault. The crucial element in this strain of melodrama is its use of pantomimes, set to music, and based on mythic, historical, or moral topics. Large word boards were used to help the audience understand the action, much like the use of print in early silent films. Pantomime Dialoguée had evolved by 1785 , characterized by fragments of spoken dialogue, and stolen operatic airias, intermixed with broad pantomimic actions on the stage (César Ribié's La Prise de Mitylène [1783] is an example). ${ }^{5}$

Finally, the last two major musical influences on the development of French melodrama were the popularity of Michel-J ean Sedaine's music-drama Richard Coeur-de-Lion (1784), itself a manifestation of the intense interest in all things British in prerevolutionary France, and Lamartellière's extremely popular musical version of Friedrich von Schiller's Die Räuber (1792), suggesting the cultural and artistic interconnections between politically hostile nations in Europe. James Boaden, himself an importer of French dramas onto the British stage, defined the new genre melodrama as "an opera in prose, which is merely spoken, and in which music discharges the duty of a valet de chambre, because her office is simply to announce the actors" (Shepherd and Womack 218). The popularity of opera throughout Europe clearly influenced stage productions, and a new confluence of artistic genres produced the "mixed" entertainments that a growing bourgeois population sought for a mirror of their own "mixed" and shifting social status. For instance, Richard Coeur-de-Lion is an early "rescue opera," one of a number of operas semiseria that depicted an aristocrat imprisoned and eventually liberated by a loyalist in a frenzy of royalist sympathies. Such operas combined political conservatism and artistic innovations to entertain the masses, flirting with the notion of overthrowing the ancièn regime only to save and restore the upper classes to their power by the conclusion of the piece. "Rescue opera," originally Italian, then French, then British, then German, ultimately culminated in Beethoven's final version of Fidelio (1814), while such a trans-European genre reveals how closely French, 
English, and German cultural works fed on each other for inspiration as well as specific devices. ${ }^{6}$

Lothar Fietz has recently discussed how August von Kotzebue's sentimental dramas in Germany were adapted for performance quickly in both England and France, while British works by George Lillo (i.e., his London Merchant, 1731) significantly influenced the direction of both French and German melodramatists throughout the eighteenth and nineteenth centuries. According to Fietz, the power of Lillo's work can be found in its presentation of a pre-bourgeois anthropology in which tragedy can enter the drama because his heroes display a belief in the bifurcation between mind and body, passion and reason. Traditional tragedy had sought its material in the conflict between a strong willed individual struggling against unjust social institutions or alternately, the turmoil between reason and passion within one individual. Both the tragic and the pre-bourgeois paradigms were to be replaced fifty years later when Schröder adapted Lillo's tale and used in his works the sociological model of presenting individuals. According to this view, human beings are characterized by their sense of personal self-worth and their belief in their own power to control society through their virtues and manners. Control of one's fate through one's actions and characteristics leads, according to Fietz, to a decidedly "un-tragic" view of life:

Within the framework of a closed system of private entities such as the family, [individualism] could contribute to a resolution of the tragic nexus. Once this point is reached, the tragic conflict can be replaced by actions that portray temporary moral confusion and that end with the reinstatement of the individual within the harmony of the bourgeois order . . . . Then, finally, in the provisional end phase of this evolution, a dissecting, "microscopic" analysis begins to focus only on the discontinuous inner life of the individual. $(85,87)$

In other words, with the triumph of the bourgeois system of morality, the fate of an entire class of people could be represented by the actions of one family, for the private and interior spheres come to ensure order, social protection, and the powers of redemption. If there is only the private, then there can be no public realm, no transcendent order, no cosmos apart from the immediate and the quotidian. The medieval beliefs in immanence and transcendence slowly are banished in favor of what the German critic Arthur Eloesser has called the "reductio ad familiam" (Fietz 86). In addition to the celebration of the 
family, there is also a celebration of the new individual, the bourgeois superhero who stands apart from both society and family. In this final phase of melodramatic evolutionary consciousness, God is banished in favor of a world-view dominated by the notion that individuals live in a society that they are increasingly able to control and dominate without external or supernatural aids. According to this paradigm, the sentimental and melodramatic would appear to be genres caught in the middle between the earlier traditional world-view of tragedy and the new consciousness of the bourgeois individual triumphing over all social constraints in a bold act of self-assertion and self-possession.

In addition to the vogue for the sentimental ethos in novels, poems, and plays, there was clearly another large and influential discourse system operating, for the late eighteenth and early nineteenth centuries were the heyday of the Gothic as a cultural semiotic. The Gothic aesthetic, with its celebration of a loyalist, chivalric code of ethics, infiltrated the stage in response to an audience that had come to expect sightings of ghosts, supernatural events, and a Manichean system of justice. Paula Backscheider argues, in fact, that melodrama is a continuation of the Gothic (174). Certainly one can claim that Monk Lewis's Castle Spectre (1798) contained a number of melodramatic elements, including the supposedly orphaned heroine, the evil uncle, and the peasant hero. And one can also see melodramatic aspects in James Boaden's dramatic adaptations of Radcliffe's novels. However it seems necessary to distinguish between gothic drama as a unique genre separate from although related to melodrama. Gothic dramas contain historical and nationalistic elements that melodramas do not. Indeed, we could claim that the two genres-like bookends-reveal the public and historical (Gothic) and private and domestic (melodrama) faces of the culture.

In trying to understand the nature and significance of melodrama as a genre, one is reminded of Louis Althusser's observations about Bertolazzi's El Nost Milan, a melodrama that focused on the struggles of a Milanese worker in the 1890s. Althusser suggested that melodramas work by juxtaposing two conflicting "horizons" or "temporalities" of understanding and desire: the overt ideological representation of bourgeois economic morality and those moments of potential that challenge the dominant horizon without actually supplanting it. Althusser called the first "horizon" the 
"sublimations and lies of bourgeois morality" and the second "the law of the heart," while he went on to observe that the dissociated temporalities of melodrama allow the audience to observe the two modes of consciousness (one "false" and one "real"), even though that second level is never fully actualized (i.e., in the heard discourses of the slave, the revolutionary, the poor) (35). Another way of articulating Althusser's observation would be to say that some melodramas offer socio-critical content while others are completely uniform in their emphasis on narcissistic, affective structures of meaning. But Althusser's position is directly contradicted by Peter Brooks's identification of Jacobin with melodramatic discourse. For Brooks, both the political position and the artistic genre are similar in that they both "privilege the logic of either/or and refuse a middle position" ("Melodrama, Body, Revolution" 37). The "middle position" to emerge from melodramas, however, is closer to what we would now see as a middle-class or bourgeois stance, not a leftist, liberal, or proletariat position.

By the time Pixérecourt composed his Coelina, the gestures, characters, scenery, and situations of Rousseau's melo-drame were established, and they were clearly a mixture of classical mythic themes, fairy tales, and historical struggles reflecting loyalty to the royalist cause through what we would now recognize as Gothic conventions. James Smith also lists as originating influences on the final shape of melodrama the drame, "that genre of serious prose tragicomedy which derives its sentimentality from Richard Cumberland and its bourgeois didacticism from the horrible homilies of George Lillo" (3). But there were other British influences on Pix' erecourt whose favorite reading in 1793, for instance, was Rev. James Hervey's Meditations and Contemplations among the Tombs (1746-47) and Rev. Edward Young's The Complaint, or Night Thoughts (1742-45). Both works typify what the French referred to at the time as le spleen anglais. As Rahill has noted, both authors were popular in France because of their "resolute moral didacticism, a morbid preoccupation with grief and misfortune, a noxious and all-pervading sentimentality, and an almost total absence of a sense of humor. All of these were to be in the inheritance of melodrama" (7). With such an unpromising list of characteristics, one wonders how melodrama survived, let alone flourished, and yet it most decidedly did. Pixerecourt himself stated that the new pieces that he was writing for the theater would succeed 
if he focused on a moral subject with inherently dramatic content in it, if he used the dialogue of average people, if he combined comedy with seriousness in the plot, if he punished crime and rewarded virtue, and if he used effective mise-en-scène at all times to further the illusion of verisimilitude on stage (Rahill 9).

The conventions of melodrama are a curious mixture, then, of musical forms, literary genres, and conservative political and social sympathies all bound up in a strikingly visual manner, suggesting the pantomimic background of the genre, with the broad gesture and the silent, mute wound at the core of the tale. Consider the prevalence of the tell-tale scar or the prominence of the portrait of the dead parent in melodramas and Gothic fictions, the theme of secret marriages or disputed inheritances in both, the letter that is either indecipherable or deceptive, the arrival of the supposedly orphaned child or parent long believed to be dead, and finally, most melodramatic of all, the conspiracy among the powerful against the innocent or the foiled in the nick of time murder or seduction plot. Pixerécourt uses all of these devices and for good measure also throws in a hero whose tongue has been cut out, thus ensuring the pantomimic nature of much of the stage action of his Coelina. Translated into Dutch, German, and English, Coelina was so popular that it ran for 387 performances on the Boulevard du Temple (Smith 6).

As was so typical of the time, Coelina the melodrama was adapted from another source, a popular novel written by FrançoisGuillaume Ducray-Duminil, well known at the time as a writer for the lower-classes. Unlike Beethoven, Pixerécourt was able to change his colors to suit the mood of the times, and therefore his Coelina simplified Ducray-Dumenil's roman noir to cohere with the about-face of the Napoleonic era, defended and illustrated perfectly with a moral tone in tune with the new Civil Code. In Pixerécourt's adaptation, the heroine Coelina is an orphan living with her uncle Dufour and courted by the wealthy neighbor Trugelin, although Coelina herself loves and is loved by the uncle's son, Stéphany (her cousin). The villain-suitor is motivated by the promise of a large dowry and adjoining estates that Coelina will bring to the marriage, all of which he reveals to the audience in a series of soliloquies that conceal none of his greed or villainy. Also living in the household of Dufour, however, is a mysterious and mutilated stranger named Françisque Humbert, a man 
who cannot speak but who conveys through pantomimic gestures his beating-narrative to his adoptive family: he was betrayed, sold into slavery on a pirate ship, and had his tongue cut out. Once returned to land, he was attacked in a wild mountainous region and left for dead. Coelina is strangely drawn to the old man, as he is to her. Such a device, called the "voice of the blood," was a standard technique also used in such gothic works as Radcliffe's The Italian, among others. But if the displaced hero cannot help being redeemed and recognized, neither can the villain. When Trugelin confides to his thuggish assistant Germain that he had beaten Humbert years ago and now intends to kill him that night, his confession is overheard by Coelina, who simply happened to be carefully hidden nearby. When his plot backfires and Trugelin himself is revealed as the villain, he resorts not to absconding but to more threats: "If I do not receive your consent [to the marriage] by ten o'clock tomorrow, tremble! A single word will break off the nuptials you plan [with Stéphany] and that word I shall utter."

All of this action occurs in the first act, while the second act begins with preparations for the immediate marriage of hero and heroine, neither of whom appear to take Trugelin's threats seriously enough to find out what it is he has to say. Following a comic interlude between two country bumpkins, the villagers gather for the wedding, and at this point a formal ballet occurs, again revealing the residue in early melodrama of music and dance as crucial pantomimic elements. This prelude is rudely interrupted by the arrival of the news that Trugelin had threatened to reveal. Amid a flourish of supposedly legal documents, he claims that Coelina is not the daughter of Dufour's dead brother, but instead the illegitimate child of Humbert (the mute) and Trugelin's adulterous sister. The recognition scene between father and daughter-so central to melodrama-occurs, but the happiness of this pair is marred by the accusations of illegitimacy and the mother's adultery, not stains that can be easily dismissed in the melodramatic universe. In accordance with the dictates of melodramatic characterization, the once amiable Dufour suddenly is transformed into an evil uncle, compelled to exile both father and daughter for their sins against the family. Dufour, of course, quickly regrets his action when he learns that it was Trugelin who had assaulted Humbert so many years ago. Exposed by the local doctor as the villain he is, Trugelin flees to the same woods where he had earlier attacked Humbert- 
scene of Act 3 most spectacular action as well as scenery, the wild mountainous pass in Savoy where all the principals meet to resolve their melodramatic fates.

Act 3 is announced by claps of thunder and the fleeing figure of Trugelin, now disguised as a peasant. The same miller who had assisted Humbert eight years earlier at the time of the assault on his person by Trugelin, now appears to assist Trugelin in his desperate bid to escape the forces of law closing in on him. As he tells his version of the events to Trugelin, the miller shakes the villain's hand and notices a large scar on it. Only later, when it is too late to easily capture him, does the miller realize who the supposed peasant was. By that time, however, father and daughter have arrived, seeking shelter. Trugelin engages once again in a struggle with Humbert and tries to kill him, stopped only when Coelina throws herself across the body of her father. When archers finally capture the villain, peasants descend, wanting to kill the man on the spot. Dufour suddenly appears-deus ex machina-and pronounces, A "Leave him to the law," a statement that reveals how thoroughly trusted Napoleon's new Civil Code had become. In other words, in lieu of the caprices of a King, now there was a system of law administered by a tribunal of the people, presided over by a secularized and omnipotent warrior-emperor. All that is left is the redemption of Coelina, and this Humbert supplies by informing the assembled that he was actually married to Isoline, whose later marriage to Dufour's brother was a bigamous one, forced upon her by the threats of her evil brother Trugelin. After a quick marriage ceremony, the action concludes with a ballad and dance signifying the closing and healing of the social unit.

So much for the plot of Pixerécourt 's version of Coelina, a work that Taylor has called "the prime example of the essentially reactionary drama engendered by the Revolution," a work that "restrained, even defused, the radical impetus for change" (203). Suffice it to say that Holcroft's version, A Tale of Mystery, is a very close translation, in two acts, with only one scene and the ending slightly changed (more on both anon). Holcroft was also canny enough to enlist the musical talents of the famous organist Thomas Busby, who composed the music for the melodrama. The interesting question for a theater historian, however, is how does Holcroft's Tale differ from 
his earlier dramatic works, and what does his knowledge and use of Pixer' ecourt reveal about the evolution of melodrama in Britain?

Most typical of his earlier works is The Deserted Daughter, written a few months after his infamous "trial" for sedition. This selfadvertised "comedy" concerns a Mr. Mordent, married to the wealthy and titled Lady Anne, a woman who does not know that her husband has an adult daughter from a prior marriage, the heroine Joanna, now living as a disowned ward, unaware of her parentage. Pressured to reveal the existence of the young woman by his friend Donald, Mordent is also being blackmailed by a Mrs. Sarsnet, who threatens to reveal the secret to his wife's family. In addition, there are two villains in the piece, Item and Grime, who are conniving to cheat Mordent of his property and sell J oanna to a house of prostitution. As she saunters through Green Park, Joanna's extreme beauty and innocent eyes attract the attentions of men about town, Lennox and Cheveril, and, more ominously, her father, a frequent visitor apparently to the whorehouse. Unaware, of course, that she inhabits a "house of contamination," Joanna is aggressively pursued by Lennox, who asks her unwitting father for his help in kidnapping her. But J oanna is also the target of Cheveril's idealized and pure love, not to mention Lady Anne's pity and acceptance. When Mordent finally does learn that Joanna is his daughter, he challenges Lennox to a duel in order to avenge what he thinks is his daughter's seduction. He learns that such a seduction did not occur because Joanna had escaped from the whorehouse dressed as a man. She now wanders around in Green Park as a handsome young man, bemoaning her fate and taking the opportunity to question all of the men who had expressed such interest in her when she was a beautiful young woman. During her session with Cheveril, she describes a missing young woman she had seen in the park: "Disowned by her family, exposed to the snares of vice, houseless, hopeless, not daring to approach the wicked haunts of men, she wanders forlorn and desolate, willing to suffer, disdaining to complain" (V, iii). Agreeing to bring this "J oanna" to Cheveril the next day, Joanna in drag next comes upon her distraught and contrite father and she puts him to the test. Mordent's response to her questions serves as his confession:

Know then that I pant for a sight of her once more, to do her the little justice that is yet in my power. Know, the wrongs she has received form me are 
NOT THE PUBLISHED VERSION; this is the author's final, peer-reviewed manuscript. The published version may be accessed by following the link in the citation at the bottom of the page.

irreparable, vile, such as could not have happened but in this world of world! Know that I, her natural guardian, have been her actual persecutor; that I drove her to the abode of infamy; that I became the agent of her ruin, the plotter against her chastity; and that, when I had set the engines of darkness and hell at work to ensure her everlasting wretchedness, I then discovered [with horror] she was my daughter! (V, iv).

The recognition and reconciliation scenes continue throughout the remainder of the play with a series of denouements: Joanna's betrothal to Cheveril, Lennox's forced marriage to his maid, the saved marriage of Mordent and Lady Anne, and the exposure and punishment of Grime and Item. In line with the law of just desserts, each character is rewarded or punished in accordance with his or her conduct, although surely Holcroft intends to focus on the father's exposure, chastisement, and redemption as allegorical of the macrocosmic paternal-political situation. His father's sins come to light, but this father is restored to his position through public confession and forgiveness by his "dependents." The similarities between this father's situation and that of George III could not have missed on Holcroft's audience.

The Deserted Daughter is very much an eighteenth-century sentimental comedy with an emphasis on preserving those objects of value that have been spoiled, tainted by hypocrisy and greed: the patriarchal family, a daughter's virginity, and familial affections. The father is flawed, and yet he redeems himself by the conclusion of the play. The hero is infatuated and ineffectual, and yet he wins the beauteous object of his adoration. The heroine is disowned and uneducated, and yet her beauty and virtue protect her and keep her inviolate until her father decides that she is pretty enough for him to claim. The microcosm, in short, is as corrupt as the macrocosm, the society for which Holcroft had nothing but disdain. And yet there is no God operating in Holcroft's sentimental universe, no fate or destiny, only chance encounters and good looks, with some luck thrown in for good measure. As Taylor notes, The Deserted Daughter moves "into the realm of domestic melodrama. Gone is the benevolent rationalist of Holcroft's earlier plays, to be replaced as an agent of salvation by the incomprehensive bluster of a Scottish footman and the artless good humour of two young lads .... The happy outcome was no longer caused by beneficial providence or enlightened good sense, but by fortunate accidents of coincidence" (103). By 1795 Holcroft had 
taken God out of the dramatic equation, but it took his study of the French model for him to realize that someone-or something besides chance-had to be operating at the apex of the melodramatic universe.

Holcroft's Deserted Daughter has been largely forgotten even by theater historians, for the work is an example of the exhaustion and limitations of one genre, sentimental comedy, while A Tale of Mystery embodies the birth of a new genre, the melodrama. But where exactly is the distinction between the two? I would claim that sentimental comedy attempts to read human character through Lavater, while melodrama reads character through Hobbes. And we can recall that Holcroft published his translation of J ohann Lavater's Essays on Physiognomy (1793) in 1806. The central premise of sentimental comedy is that character is knowable and that it can be understood by studying the shape and contour of the face, which in turn can be read by mastering a few simple rules about slant of eyes, shape of mouth, width of forehead. Character is transparent, hence the scene where J oanna is presented with a portrait of a man she does not know to be her father and she immediately and accurately pronounces him a very "mixed" character, part evil and part good. Melodrama presents instead a universe in which much is hidden, including the basic nature and motivations of the people we think we know. In the melodramatic universe it is a shock when a man attacks and tries to murder his brother, as in A Tale, just as it is a total surprise that a mute stranger who shows up on one's door can turn out to be one's supposedly dead father. Melodrama initially begins in a world that everyone seems to have mastered, but in fact all are inhabiting a society in the grip of lies, illusions, or deceit. The logic of the melodramatic world-view works toward confrontation with the mysterious, unknowable, and hidden until there is a veritable public and private explosion and the truth is revealed in the most painful and humiliating way possible. In the conclusion, all the characters sort themselves out by realigning into tighter and closed clan or tribal units, all of which vindicates the value of maintaining a rigid class system. But there is always a residue left from the melodramatic conflict and that trace is the recurring theme of the survival of the fittest. In sentimental works it is the survival of the prettiest, but in melodrama it is the survival of the most virtuously bourgeois. A secularized moral tenor pervades melodrama, but the voice of morality is not male, nor is it aristocratic, nor is it divine (all of whom still occasionally raise their heads in sentimental 
works). The melodrama evolved in England as a vehicle by which women, specifically lower-class women, were given the final word, and that word was the voice of simple common sense.

We can see some of these shifts in emphasis by looking at the changes that Holcroft made as he adapted Pixer' ecourt to the British stage. As I noted earlier, he made two primary changes, both toward the conclusion of the play. My focus will be on those two changes, for they reveal the uniquely British J acobin quality of the adaptation, while at the same time they display Holcroft's political, social, and (anti) religious agendas. Simon Shepherd argues that Holcroft's revisions of his French source reveal a new subjectivity, an anarchistic posture toward both the state and the family, a condemnation of marriage and a much more complicated position toward justice, law, class structure, and family (510-511). But what is most important in Holcroft's revision of Coelina is that he removes the villain's prayers to God after his capture and instead inserts an earlier scene in which Fiametta, the maid, takes essentially the place of God. In Holcroft's adaptation, Bonamo (the Ducour figure) refuses to allow his nephew Sephano to marry Selena once he learns that she is illegitimate. Despite the pleadings of his nephew, Bonamo threatens to disinherit and curse him should he marry without his consent.

This impasse, however, is quickly resolved when the servant Fiametta enters to tell her employer exactly what she thinks of his decision: "I don't care for you. I loved you this morning; I would have lost my life for you; but you are grown wicked" (II, 34). When Bonamo tries to silence her, she continues to speak in a manner that no female servant had spoken to a male authority figure before on stage: "I know the worst: I have worked for you all the prime of my youth; and now you'll serve me as you have served the innocent wretched Selina; you'll turn me out of doors. Do it! But I'll not go till I've said out my say: so, I tell you again, you are a hard hearted uncle, an unfeeling father, and an unjust master! Every body will shun you! You will dwindle out a life of misery, and no body will pity you; because you don't deserve pity" (II, 35). For the first time on the popular British stage a female housekeeper, a servant, issues orders to and offers words of condemnation to her aristocratic employer; it is she who has assumed the voice of moral authority in the play. It is she who will forgive or not and allow the master to continue in society, not God, not 
anyone else. As Shephard notes, early bourgeois British dramas were predicated on the exclusion, marginalization, and victimization of female characters, all of which served the "male-centeredness" of the stage's actions and the audience's expectations. Artisan culture was itself the product of working practices that ensured a "closed shop," a union that excluded women as workers (514). Such a culture expected to see men at the center of the stage, not women, and hence the gothic - with its victimized and orphaned heroine in need of male protection and intervention-very much suited its tastes. What is most revolutionary about Holcroft's Tale of Mystery, however, is its positioning of the woman-and a maid-at the center of the stage and as the voice of moral and social authority.

In the earlier play, The Deserted Daughter, we saw a young woman, disowned, parentless, who finds a husband and reunites with her redeemed father through no action more strenuous than wandering around Green Park dressed as a man. The action is incidental to the identity of the heroine. Her very being-and her beauty and innocence-assure her success; her actions are ancillary to the preordained conclusion wrought by the sentimental universe. In the later play, A Tale of Mystery, the heroine sleuths, uncovers a murder plot, aligns herself with her disgraced father, and then pleads for her evil uncle's forgiveness as the soldiers close in on him in order to kill him. We do not see her aligned with her fiance Stephano in Holcroft's version, although clearly a marriage is promised. Instead, we see her standing between father and uncle, the feminine mediator in a system of masculine dyadic dysfunction. Both heroines are daughters and both are very much the center of the action. And yet in the latter play, Selena is more than a daughter functioning to prop up a tottering and corrupt patriarchal system. She is a social arbiter, a political advocate who cautions against rash revenge and instead pleads for forgiveness and acceptance of those who have committed even the most heinous crime against their fellows. In short, the evolution of melodrama is predicated on the emergence of lower- and middle-class women as forces to be reckoned with in an increasingly secularized society. God is replaced in the melodramatic universe with wise women who do not hesitate to speak truth to power.

So if speaking is the issue, why is the hero mute? When Shepherd attempts to answer this question he observes: 
NOT THE PUBLISHED VERSION; this is the author's final, peer-reviewed manuscript. The published version may be accessed by following the link in the citation at the bottom of the page.

The emotion of the moment of speaking out is something very different from the frustration experienced when the dumb man cannot speak to clear himself. Being able to acclaim the truth is the opposite of being trapped into a false truth. Melodrama may be said to construct excitement out of the possible alternation between being trapped in circumstances and being able to change them. (201)

For Shepherd, the rhetoric of false virtue and self-serving hypocrisy can only finally be defeated by the ontological reality of truth, which does not speak; it simply is. Whereas Shepherd wants to argue that melodrama serves a liberal agenda, Taylor insists that melodrama is inherently conservative, invested in depicting "tradition as innocent and change as evil" (205). Peter Brooks, on the other hand, points out the highly metaphorical aspect of muteness, arguing that the mute gesture is "a displacement of meaning . . . whose tenor is a vaguely defined but grandiose emotional or spiritual force that gesture seeks to make present without directly naming it, [and instead] by pointing at it" (Melodramatic Imagination 72). But what exactly does the mute hero point to but his own maiming, his own castration at the hands of a patriarchy that he himself was/is part of? Lest readers think that melodramas are too "thin" to be looked at from psychoanalytical lenses, consider Brooks's comment on the subject:

Psychoanalysis is a version of melodrama first of all in its conception of the nature of conflict, which is stark and unremitting, possibly disabling, menacing the ego, which must find ways to reduce or discharge it. The dynamics of repression and the return of the repressed figure the plot of melodrama. Enactment is necessarily excessive: the relation of symbol to symbolized (in hysteria, for instance) is not controllable or justifiable. The Evil of melodrama is reworked, only partly de-ethicalized, in the process of repression and the status of repressed content; the unconscious is ever ready to act as le traître. The structure of ego, superego, and id suggest the subjacent Manichaeism of melodramatic persons and indeed the characters most often put on the stage. (Melodramatic Imagination 201)

Melodramas enact cultural anxieties through rhetorical devices that swerved violently between hyperbole to mute silence, all the while enacting a moral code that was complicitous with a conservative political agenda. Such a strategy served to defuse freefloating cultural anxiety by first enacting the worst that could happen and then containing it. This technique reassured its audience that evil would be recognized and punished, good would be restored and vindicated, and stability and harmony would triumph over the capricious or chaotic. 
What ideological role did melodramas play, then, in the evolution of early nineteenth century British culture? I would contend that melodramas, like all literary discourses, served a bifurcated ideological function, both liberal and conservative causes. Melodramas - like classical Greek dramas-enact ancient fertility rituals, complete with symbolic castrations (mutes) and besieged virgins, in order to perform a quasi-religious function in an increasingly secular society. Melodramas, in short, are about the struggle to remain a believer in a world that does not deserve belief. ${ }^{7}$ God is absent, but His presence is mourned in the melodramatic universe. The god that failed in melodrama is embodied in the evil uncle, the corrupt father, the patriarch who oppresses and seduces. And the savior is the daughter/mother figure, a class indeterminate woman who reminds her culture that life has value in and of itself and that familial codes of appropriate conduct must function in lieu of abstract and outmoded religious principles. The melodrama works to make social and class relations feel like familial structures, the public becomes privatized, or as Shepherd observes, the melodrama "makes [the] forms and structures of society feel like private relations, elements of the inner person" (508). But there is also the curious flatness in melodramatic characters that makes discussion of their inner lives so problematic. Hadley notes on the same scene:

melodrama situates law and morality in a public performative space inhabited by social and familial relationships rather than within the private spaces of individuals or in God. The public sphere itself, defined by social feeling and filial action, is both the site and origin of melodrama's powerful operation of providence so that sacred human comities, not an individuated God or fate or a despotic ruler, provide the instructive lesson. (71)

Stories from the Bible, Shakespeare, and Greek or Roman mythology were no longer presented as models to a population that clamored for tales of secular heroism, while, as Taylor notes, psychological dramas now replaced spiritual journeys and the action was "loosely metaphorical rather than strictly allegorical" (29). The poetic psychomachias of Blake, Byron, Wordsworth and Coleridge found their theatrical equivalents in the melodramatic agonies of suffering daughters and guilt-ridden fathers, who in turn were metaphorical equivalents to a British populace ruled by a periodically insane king. As Fredric Jameson notes, the "political unconscious" of a nation is revealed in its symbolic enactments of a social narrative, and 
the master narrative of this particular society was repression, longsuffering, and acceptance of a flawed political system that was preferred over the chaos that could result from revolution. 8 Melodrama spoke to the "political unconscious" of bourgeois Britons because it enacted their own "mixed" and ambiguous feelings toward an insane ruler and a society committed finally to incremental change. How ironic that a committed political radical should be credited with importing melodrama, a genre that Taylor has termed "the classic reactionary genre" (199), into Britain. And how significant that the changes Holcroft made in his French source caused melodrama to swerve toward the increased power and prominence of lower and middleclass women as social arbiters in this new bourgeois nation. One of the legacies of Holcroft's swerve can be seen in works like Jane Eyre or Wuthering Heights, where servants frequently chastise aristocrats for their folly. Holcroft revealed the moral vacuity at the heart of "the temple of morality" that aristocratic Britain had constructed for itself, while he attempted instead to erect an alternative "temple of morality," a nascent J acobin stage presided over by a sharp-tongued maid who was morally centered enough to understand that society was based not on outmoded codes of rank and privilege, but on forgiveness, generosity, and human decency.

\section{Notes}

1 See Holcroft's A Tale of Mystery-A Melo-Drame (London: Phillips, 1802); manuscript submitted for licensing November 4 1802. A literal translation of Pixerècourt's souce was published by John Wallace as Coelina: or A Tale of Mystery (London: privately printed for Wallace, 1802). Wallace submitted his script to Covent Garden for performance, but it was rejected. He had his version of the play published "for his own satisfaction" and in order to coincide with the production of Holcroft's play (Shepherd 520, n5). Such a move suggests that Holcroft's politics were not forgotten in London, or perhaps that copyright consciousness was growing.

${ }^{2}$ George Taylor identifies Inkle and Yarico by George Colman the Younger as the first "mixed" work, with thirteen songs, a comic tone, and on the potentially tragic subject of the slave trade. He cites Alan Sinfied's definition of a "cultural faultline" to explain the genre: "Faultline stories are the ones that require most assiduous and 
continuous reworking; they address the awkward, unresolved issues, the ones in which the conditions of plausibility are in dispute [ and which] comprise within themselves the ghosts of the alternative stories they are tying to exclude" (40).

3 The Deserted Daughter (Covent Garden, May 2 1795) was considered by Hazlitt to be "perhaps the best of Mr Holcroft's serious comedies" (Life of Holcroft, II, 95). Ellis very helpfully reviews the terms sentimental, comedy, and sentimental comedy in a morphological attempt to discern the specific qualities of sentimental comedy, while Sherbo defines Sentimental Drama and tests his definition against a number of works, including Holcroft's Deserted Daughter (162, 164165).

4 Percy A. Scholes, Oxford Companion, 9th edn 1955, 624; Shepherd and Womack 194. A more detailed definition of the genre has been provided by Rahill:

Melodrama is a form of dramatic composition in prose partaking of the nature of tragedy, comedy, pantomime, and spectacle, and intended for a popular audience. Primarily concerned with situation and plot, it calls upon mimed action extensively and employs a more or less fixed complement of stock characters, the most important of which are a suffering heroine or hero, a persecuting villain, and a benevolent comic. It is conventionally moral and humanitarian in point of view and sentimental and optimistic in temper, concluding its fable happily with virtue rewarded after many trials and vice punished. Characteristically it offers elaborate scenic accessories and miscellaneous divertissements and introduces music freely, typically to underscore dramatic effect. (xiv)

Other historical overviews of melodrama as a genre can be found in Bentley, Brooks, Booth, and Donohue.

5 Smith, 1-3. For a more theoretical approach, see Heilmann who argues that in tragedy the hero is "divided," and therefore no villain is needed because the hero is betrayed by warring forces within himself. In contrast, in melodrama the protagonist is "whole," always acting with one single purpose and free from all ambivalences, opposed only by external forces, not internal ones (34).

6 The relation of "rescue operas" to literary genres such as the Gothic and sentimental is discussed in Hoeveler and Cordova. 
${ }^{7}$ Consider the popular I rish melodramatist, Dion Boucicault (182090), whose "The Shaughraun" (c. 1858) fashions the title character as a traditional trickster figure, at one point laid out in his coffin while the community mourns his death. Con, the Shaughraun, is only pretending to be dead in order to expose the traitors who are in league with a corrupt magistrate and British soldiers in order to capture the Fenian hero. The climax occurs when the Irish villagers close in on the villains intending to kill them, and the priest confronts them, "Are you Christians or heathens?" They pause before putting their knives and axes aside to allow the police to make an arrest. The humor of the scene occurs in the hesitation, as the villagers debate the question and slowly put their axes down. Such a scene reveals the role that melodrama played in moving religious beliefs out of the church and into the public space of an increasingly secular society.

8 See Jameson 58-67. Watkins argues that all Romantic drama should be read in the context of political change, noting that there is "a conflict between the content of surface structure and a deeper political unconscious [which] registers one of the key features of the Romantic historical moment: namely the difficult struggle that marked the transition from an aristocratic to bourgeois worldview" (8). Taylor argues that melodrama is a reactionary legacy of the Revolution, while the subtext of Coelina is that "trust must be restored-even if it is an irrational trust in the nobility of the aristocrats and the benevolence of the bourgeoisie" (204).

\section{Works Cited}

Althusser, Louis. For Marx. London: Verso, 1969, 135.

Backsheider, Paula. Spectacular Politics: Theatrical Power and Mass Culture in Early Modern England. Baltimore: J ohns Hopkins U P, 1993.

Barrell, J ohn. Imagining the King's Death. Oxford: Oxford U P, 2000.

Bolton, Betsy. Women, Nationalism, and the Romantic Stage: Theatre and Politics in Britain, 1780-1800. Cambridge: Cambridge U P, 2001.

Brooks, Peter. The Melodramatic Imagination. New Haven: Yale U P, 1976. 
-. "Melodrama, Body, Revolution." Melodrama. Ed. Jacky Bratton et al. Melodrama: Stage, Picture, Screen. London: British Film Institute, 1994.

Ellis, Frank H. Sentimental Comedy: Theory and Practice. Cambridge: Cambridge U P, 1991.

Jameson, Fredric. The Political Unconscious: Narrative as a Socially Symbolic Act. Ithaca: Cornell U P, 1981.

Fietz, Lothar. "On the Origins of the English Melodrama in the Tradition of Bourgeois Tragedy and Sentimental Drama: Lillo, Schroder, Kotzebue, Sheridan, Thompson, Jerrold." Melodrama: The Cultural Emergence of a Genre. Eds. M. Hays and A. Nikolopoulou. New York. St. Martin's, 1996. 83-101.

Gregory, Allene. The French Revolution and the English novel. 1914; rpt. New York: Haskell, 1966.

Hadley, Elaine. Melodramatic Tactics: Theatricalized Dissent in the English Marketplace, 1800-1885. Stanford: Stanford U P, 1995.

Hazlitt, William/Holcroft, Thomas. The Life of Thomas Holcroft, written by himself. Continued to the time of his death from his dairy notes and other papers by William Hazlitt. Ed. Elbridge Colby. London: 1925; rpt. New York: Blom, 1968. 2 vols.

Heilman, Robert B. Tragedy and Melodrama. Seattle: U of Washington P, 1968.

Hoeveler, Diane Long and Sarah Davies Cordova. "Romancing the Throne: 'Rescue Operas' and the Gothic Genre." British Opera. Eds. Michael Eberle-Sinatra et al. Aldershot, UK: Ashgate, in press.

Holcroft, Thomas. The Deserted Daughter. Rpt. The Plays of Thomas Holcroft. Ed. Joseph Rosenblum. New York: Garland, 1980. 2 vols.

-. The Tale of Mystery. Rpt. The Plays of Thomas Holcroft. Ed. J oseph Rosenblum. New York: Garland, 1980. 2 vols.

Kelly, Gary. The English Jacobin Novel 1780-1805. Oxford: Clarendon, 1976. 
NOT THE PUBLISHED VERSION; this is the author's final, peer-reviewed manuscript. The published version may be accessed by following the link in the citation at the bottom of the page.

Rahill. The World of Melodrama. University Park: Penn State U P, 1967.

Shepherd, Simon. "Melodrama as avant-garde: Enacting a New Subjectivity." Textual Practice 10 (1996), 507-522.

-and Peter Womack. English Drama: A Cultural History. Oxford: Blackwell, 1996.

Smith, James L. Melodrama. London: Methuen, 1973.

Taylor, Gary. The French Revolution and the London Stage, 17891805. Cambridge: Cambridge U P, 2000. 